Article

\title{
Television News in the 1950s: \\ New Medium in the Service of Soviet Power and Society
}




\section{ABSTRACT}

The article discusses the evolution of conventions for TV-journalism based on the early history of Estonian Television (ETV) news. ETV was launched in 1955, its founding was coordinated by the Soviet authorities in Moscow. Although one of the initial motivations for founding the station was to produce ideological programming directed to Finnish audience, the Estonian team within the institution used the new medium to develop a new nationally oriented media organization. Over time this new journalistic institution became increasingly established and standardized both in terms of its practices as well as its use of textual formats. As the authorities lacked a clear understanding of television's specific journalistic means and affordances the governance of ETV became an object of a rather multilayered control system. The article analyses this complex system of institutional power distribution and discusses its effects on the evolution of "cognitive modalities" expressed in specific programming formats, especially in regard to mechanisms of representing time and space. Also the "interpretative modalities" or the various, often conflicting mechanisms of managing "collectively shared meaning-systems" are discussed. For instance, in response to ritualistic and non-dialogic elements of the program that were conditioned by the soviet ideological apparatus the local journalists also aimed at representing the quotidian experiences of the common men and at establishing relatively free and dialogic relationships with their audiences and with their sense of reality. As a result, the program evolved as a mixture both ideologically and modally different as well as, paradoxically, mutually conditioning elements.

INTRODUCTION

An analysis of scripts from the first

Estonian television broadcasts enables one to describe the evolution of the role of television from a passive aggregator of newsreels and rather primitive studio performances to an independent producer of television news. The first newsreel produced specifically for television was aired on 11 March 1956. Here independence is, to a great extent, a conditional term; television studios in Tallinn, the capital of Estonia, 
were under the tight supervision of totalitarian authorities as Estonia was part of the Soviet Union. As a new communication technology, television was a new ideological instrument for powerholders. But as the analysis of historic television scripts shows, television as a technological environment cannot be fully controlled. Independence means that there are always elements of a collective perception of reality and meaning-production that could be independently handled even under totalitarian rule. In addition to the institutional dimensions of the journalistic construction of reality, there are always certain experiential and interpretive mechanisms regarding the interaction between content providers and the public.

The story of television's first years in Estonia is partly a story of a new medium of the times that served as a completely new environment for the construction of journalistic facts and texts. The audience of this new medium soon became a public in its own right-an independent television public. Even in a totalitarian setting, the powerholders were unable to establish complete control over that public as they could not control collective meaning production that could arise from the interpreting and recognising of various texts. As the new medium of the times, television provided effective opportunities for visual communication and new sociopragmatical dimensions of texts. It can be concluded that there is a public sphere even in a totalitarian society that is somehow independent from the powerholders. Institutional mechanisms are always present, especially for any new technology, and questions regarding the scope of institutional control are valid nowadays as well.

This analysis is based on the full corpus of newscasts by Estonian Television (ETV) during its initial period of operation, 1955-1958'. The news was broadcasted chiefly in Estonian and in Finnish. Here the entirety of the broadcast scripts is essential. As described by Gunter (2000: 66), this

Full records can be found as Tallinna telestuudio saatetekstid (Fond RA 1590, records in the National Archives of Estonia). enables one to analyse decision-making in detail, to see what issues were included or excluded in the programmes, what events were covered, and under which circumstances. For example, there was often a delay in journalistic coverage for reasons not justified by technological constraints but rather for ideological reasons.

One challenge is that most of the picture material was destroyed in a fire during the 1960s. Still, picture usage can be analysed as part of specific language usage. In some cases, some written remarks can be found. The construction of facts for the public involves the use of language for a particular purpose in a certain social setting. Thus, the method of analysis of journalistic fact construction is founded on sociopragmatics, a discipline that describes the relationship of language with its environment. In journalistic communication, facts are presented according to the belief that the audience will accept them as a reflection of the reality they share with the journalist even in the totalitarian framework.

The theoretical foundation for this analysis is provided by critical communication theory and the study of journalistic texts from the viewpoint of social perception. Based on generally acknowledged approaches to mediated communication (e.g., Jürgen Habermas, George Gerbner, Teun van Dijk, and others), one can develop a sociopragmatic model of journalistic fact construction to account for a set of universal aspects encountered in relation to the presentation of facts in journalism.

Those aspects can be collectively referred to as the mode of presentation of journalistic facts and can be subdivided into three modalities: the institutional, the experiential, and the interpretive. For the first stage, the institutional background is explained. Institutional framework, management issues, and features of journalistic routine can be described on the basis of archive records (such as television studios' thematic plans, budgets, and regulatory documents, as well as records of meetings of the Communist Party's local branch and correspondence with central authorities 


\section{MECHANISMS}

\section{INSTITUTIONAL}

\section{Outer mechanisms:}

- Legal norms and restrictions on content production

- Censorship

- Management, hierarchy of decision-making

- Financing of production

- Access to information

\section{Inner mechanisms:}

- Formats and genres of production (professional setting of production)

- Technological constraints of production

- Status of authorship (personality and anonymity of texts)

EXPERIENTIAL

\section{Referential management:}

- Space builders and deixis in texts

- Point of reference created by the texts

- Dominant active actors (subjects) and objects in texts

- Other actors, collective actors (such as the nation); i.e., agency

\section{Synchronization management:}

- Expressions of time, also tenses used in texts

- Presentness created by texts

\section{INTERPRETIVE}

\section{Markers of rhetoric with audience,} management of collectively shared meanings:

- Active engagements such as invitations, warnings, etc., signifying the audience's presuppositions

- Negation

- Speech acts

\section{Modalities of necessity and possibility: \\ - Discursive strategies, such as constructive strategy, strategies of justification, transformation and destruction \\ - Figures of speech, such as metaphors, etc.}

TABLE 1. Markers of the qualitative analysis of the texts and journalistic environment. 
in Moscow). Also, annual reports of the General Directorate for the Protection of State Secrets in the Press under the Council of Ministers of the USSR (GLAVLIT) were included in the analysis. The qualitative analysis of scripts consisted of reading all the texts to identify the dominant experiential and interpretational mechanisms, some of which are given as examples in this article. The basic analytic markers are summarised in Table 1. For defining experiential markers, the theoretical concept of the deictic field (Bühler 1990) and space builders (Fauconnier 1990: 40) were used; also, agency was described by Halliday (2004: 297). The concept of discursive strategies was elaborated upon by Wodak (1999:37).

\section{TELEVISION IN SOVIET ESTONIA IN THE FRAMEWORK OF INSTITUTIONAL POWER}

From an institutional point of view, the Soviet period (1940-1991 in the case of Estonia) can be broken down into smaller time periods according to specific extensive and harsh repressions that were undertaken to establish power relations in occupied Estonia. Beginning in the mid-1950s, Stalin's cult of personality was replaced by Khrushchev's partial de-stalinization and so-called Thaw, which brought some freedom of information in the media, arts, and culture. At the same time, in the Eastern bloc (the communist states of Eastern and Central Europe), various liberalization attempts were crushed by Soviet troops.

One of the first definitions of totalitarianism given by Mussolini states "everything in the State, nothing outside of the State, nothing against the State" (Brooker 2009: 17). This definition accurately describes the context of the Soviet Union during 1950s. It was not more leader driven than Stalin's regime. Friedrich and Brzezinski (1956) described an abstract collective totalitarian power system governed by a party. Lauristin, Vihalemm and Tallo (1997) described totalitarianism as being characterized by the suppression of civil society and normative public life and hierarchisation. Lõhmus identified the period from 1956 to 1960 s as when "the
Soviet semiosis and sign-system gradually became comprehensive and enabled different discourses and language games, so that journalists learned to use complicated forms of different expression, writing 'between the lines', so to speak" (2002: 21).

Here the paradox is that the decision to establish a television studio in Tallinn was already made before Stalin's death (evidence of this is a letter from local leaders of the Communist Party to Moscow; ERAF 1-5-50). Thus, the new medium was not a symptomatic sign of partial democratisation. In fact, one of the principal considerations for the Soviet authorities agreeing to establish ETV as a separate entity was its suitability to conduct an ideological campaign vis-à-vis capitalist Finland. The ETV's Finnish newscasts would evoke images of a successful and contented Soviet lifestyle; i.e., they would construct what could be termed as an "alternative reality".

The importance of television for the Soviet people was explained in detail in a special manual for official lecturers (socalled agitators). They were recruited to promote the achievements of Soviet society in regular public lectures delivered at enterprises and collective farms. Television was described as a new effective medium to deliver positive messages as a sign of happiness. But according to ideological principles, it was not just a new technology that guaranteed success, but was also the way it was used. As the manual stated,

In the Soviet Union television operates to serve progress, peace and nations' friendship initiative. In capitalist countries television is used in completely another way. There it is a weapon of fraud and slander, a mouthpiece of the most reactionary, disgusting, hostile propaganda, a tool for poisoning and mental enslavement of ordinary citizens. There it is used to remove working class from the fight for peace, democracy and socialism. (Aleksejev et al. 1955: 4). 
Thus, both technology and its functions were evidently distinguished; in a clumsy way, both the hardware and software of television were defined. Socialist society itself would have become an important ingredient in addition to the technology; otherwise, the true potential of the new technology could be wasted. The role of the state in managing television production and journalistic content was viewed as a norm in university journalism textbooks. "Soviet TV programmes are first of all human and progressive, because all depends on expectations, prescribed by the state" (Фирсов 1971: 157).

In practical terms, in order to safeguard all the virtues of television, all decision-making was very centralised. Everything regarding the establishment and development of a new television studio in Tallinn was carefully planned and monitored by the central Soviet government in Moscow. Among other considerations, the Central Ministry of Trade coordinated the manufacturing and sale of television sets. Thus, not only production, but also the reception of the broadcasts was subject to strict central planning. Estonia was a bit different from the other republics of the Soviet Union as they had a remarkable number of radios. Also, there was a strong tradition of listening to the radio as well as producing radio broadcasts. After World War II, this became a problem for Soviet authorities, as people regularly listened to foreign (i.e., capitalist) radio stations. Listening to these foreign stations was not legally banned, but the powerholders did not tolerate it. The status of a newly created television studio in Tallinn was described as "a hub for ideological work, producing content for broadcasts and being responsible for ideological and creative quality" (Leopold Piip, Director of the Tallinn Television Studio, speech delivered on 19 October 1956).

In the mid-1950s, television was mainly a local medium, although the central government's ambition was to create an effective system for transmitting unified messages and centrally produced content.
However, it was hard to set up a network that would cover the entire vast territory of the Soviet Union. On New Year's Eve of 1955, a live transmission from Moscow was planned, but the technical journal of television studio in Tallinn reported that, "In reality the programme was aired from Tallinn." The point-to-point link with Moscow did not work properly. After establishing a central television studio in Moscow, the next idea was to connect important cities with microwave relay links to transmit television programmes. But it was still not reliable enough to operate on a daily basis, such as to transmit daily newscasts. These technological disadvantages left local Estonian authorities and the managing staff of the Tallinn Television Studio some room to manoeuvre. They could propose their own ideas for the small screen. At the beginning of television, newsreels, films, and recorded concerts were centrally produced in Moscow. But these took a long time to produce and were not suited for live television.

Figure 1 shows an example of a cover sheet used for a script folder. The approval of the general director of the studio was needed. The institutional mechanisms included the control exerted by the authorities, either directly or through journalistic hierarchies, on the selection and publication of journalistic material.

The formation of television was very confusing for the Soviet censorship institution GLAVLIT. In Estonia, radio broadcasts were censored according to the law issued in 1940. It described measures "to advance measures of political control and keep state and military secrets" (17-1-5). For radio broadcasts, a principle of copy approval was applied, and all the scripts were read and amended. Every word had to be written beforehand, and a special sign (MB) "approved" was used (Veskimägi 2005: 56). For technical reasons, censors proposed that the volume of live radio broadcasts should be decreased, but early television programmes were mainly live programmes for technological reasons. The censors' work was based on paper scripts. In television, more and more spontaneous texts 
were delivered during live programmes. The annual report of the Tallinn branch of GLAVLIT said that with the coming of television, their censor's workloads had been remarkably increased (Annual Report 1955). A practical compromise for live television interviews was to approve all the questions and to discuss beforehand the potential content of the interview (Veskimägi 2005).

However, television journalists often did not present their texts to the censors, referring to operative nature of the material. In 1957, an annual report of the Tallinn GLAVLIT claimed that censors should take more active roles in the journalistic process to guarantee results. The deputy head of the office, Ažnin, said, "it is not normal for censors to go journalists' office to go around and look for texts" (R-17-2-30-1.3).

In addition, measures regarding authorship and people taking part (e.g., the journalistic choice of guests or speakers) in television programmes were seen as institutional matters. The management authorized all guests and they were often paid for their performance.

An analysis of the institutional framework of early television has revealed interesting dichotomies:

\section{Technology vs. control}

Television was a proof of the Soviet's competitiveness on the Cold War's homefront (Roth-Ey 2011: 178), and at the same time, the launch of Sputnik 1 was being prepared for. However, there was not sufficient knowledge about real television production or the specifics of visual communication through small screens, besides the traditional feature films and newsreels. In such an environment, there was no understanding of how to control television content in the most appropriate way.

\section{Creativity vs. technical production} Regarding the political context, there were domains governed centrally by the Communist Party as well as domains outside the direct party leadership. After Stalin's death, a more universal and pure collective leadership was sought after. The new doctrine was defined during the 20th Congress of the Communist Party. Also, in Tallinn Television, the Communist party oversaw content production but not much technical management. In real television production, the distinction between these two is rather vague. Therefore, this allowed some flexibility for journalists, directors, and cameramen, all of whom did not belong to the Communist Party, although they were still formally accountable to the Party (to heads of departments, editor-inchiefs, etc.).

\section{Canonical (sacred) texts vs. simple (harmless) journalistic texts concerning daily life of ordinary people}

As Lauristin and Vihalemm (2008:3) have stated, during the 1950 s and 1960 s, besides the texts having the highest level of importance, other levels of texts emerged. Culture and daily life were considered to be harmful from the institutional point of view. Political control became more differentiated.

\section{Western (capitalist) approach vs. Eastern (socialist) approach}

Television in Soviet Estonia was seen as an important tool to demonstrate the advantages of socialism for Finland. The initial idea was to start with regular television broadcasts before Finland. In special programmes in the Finnish language (the first broadcast in Finnish was broadcasted on 3 October 1956), certain linguistic constructions were avoided (for example, the use of "Estonia" instead of "Soviet Estonia"). But there was another, rather indirect, relation to the dichotomy regarding individual consumption. As Khrushchev stated, Soviet leadership had abandoned the needs of the average Soviet citizen and tried to pay more attention to consumer goods. For a long time, 


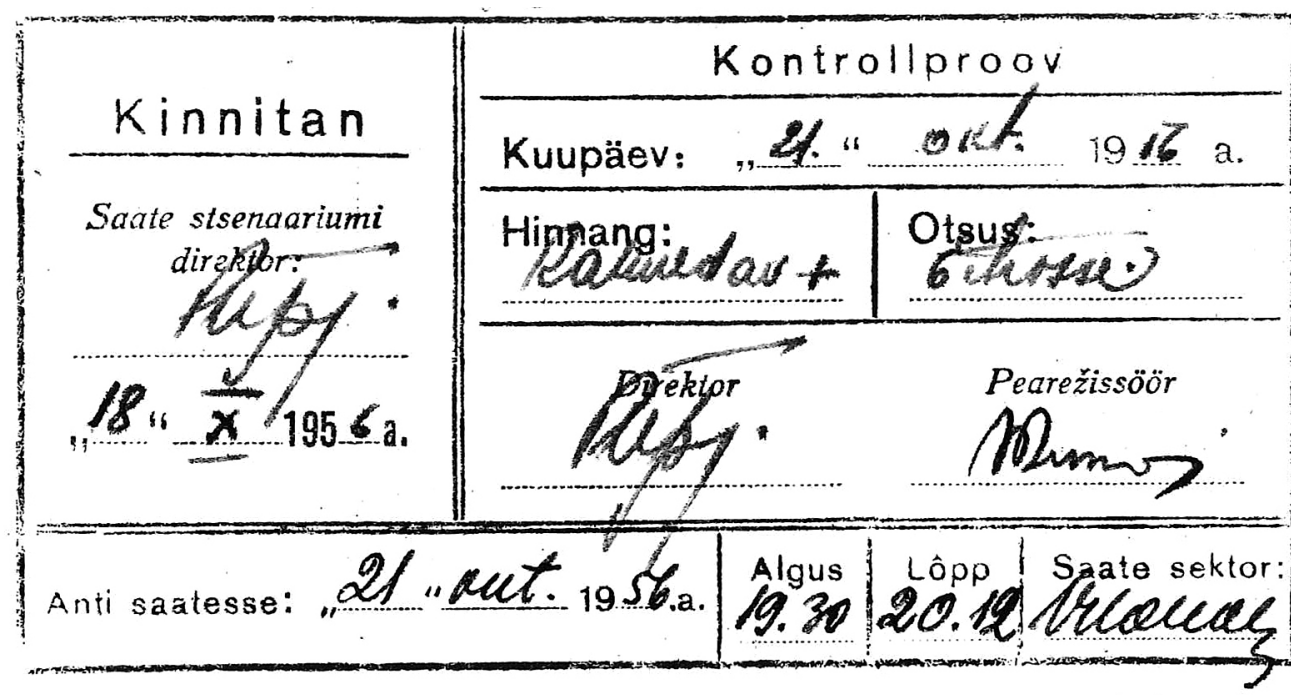

\section{Tallinna Televisioonistuudio}

saade $21.0 k$ toobril kell 19.30.

\section{Televisiooniringraade}
"A $\mathrm{k}$
$u \equiv a . n$ e. $k$
$\dot{k} a \mathrm{~m} \odot \mathrm{r}$
a is
$\operatorname{nr} .10$

FIGURE 1. Cover sheet for a script folder of the live television newscast

"Aktuaalne Kaamera" ("Current Camera") aired on 21 October 1956. By the tenth broadcast, a certain standard had been established. The script for live production was approved three days before airing (18 October 1956). Cencor did not express any concerns. The quality of the newscast was rated as "Satisfying + " ("Rahuldav +"), which was typical for the majority of newscasts. 
consumption was regarded as a capitalist phenomenon.

\section{SYNCHRONIZING REALITY AND ITS COVERAGE - EXPERIENTIAL MECHANISMS OF EARLY TELEVISION JOURNALISM}

From the journalistic point of view, with the coming of television, a new question emerged - namely, how to ground the journalistic texts in the images shown during live television broadcasts. Such a form of grounding or anchoring can be seen as a television-specific mechanism. The experiential modality of journalistic representation refers to the reflection of reality through the use of a set of synchronisation techniques typically used in news texts. They operate on a meta-textual level of audience expectations, which is independent of text tokens and helps to define the meaning of individual texts (Treufeldt 2012: 56).

At the time, television broadcasting in Estonia gave birth to one of the first Soviet television critics and enthusiasts, Vladimir Sappak, who wrote that television and the present time were much closer than one might expect. "It is namely television which lives with us, much more than other creative arts. It is at most related to our real life, not just in general sense but in the most mundane sense" (Sappak 195: 64). This kind of relationship was not clear for authorities, but was somewhat better understood by journalists. Television could become a reality of itself, a certain vehicle to represent real time similar to any online system.

Perception is individual and the principle of the mediation of experience from individual to individual. Emerging television provided new opportunities to develop new synchronization mechanisms and new opportunities for journalistic mediation of perception (i.e., experience). In journalism, synchronisation depends on the creation of certain meaning structures or events (Gerbner 1964, 1973). Some events could become important, some are ignored, and they are typically filtered by a news net. "The news net imposes order on the social word because it enables news events to occur at some locations but not at others" (Tuchman 1980: 23).

Soviet powerholders had their own official concept for an event. Qualitative analysis of scripts reveals principles of official agenda setting and news values. Abstract historic periods, developments such as revolution, or winning World War II were considered to be the most important events, as well as long-term processes, such as industrialisation and collectivisation. In more general terms, there was a conflict between the constant presentness provided by television as a new medium and the concept of real official highlights of Soviet life. According to the criteria of official agenda setting, events could not be simple and just related to daily routine. Sensationalism and exceptionality were considered to be values of capitalist journalism. Real events had to be a consequence of logical development, such as industrialisation and collectivisation. One of the presentations during the first congress of the Union of Journalists of the Soviet Union declared,
Often it has been said that information should be eventful, it should deliver facts about today's or yesterday's events. But we should be more clear and precise in defining today's events. First of all they are related to workers' exploits, their creative enthusiasm, their high-minded achievements, which describe high-spirited features of the new world. (Satjukov 1960: 54)

Such stories of personal achievements could be used to prove historic developments.

Figure 2 summarises the main principles of agenda setting in early television newscasts in Estonia as an hierarchy of events. Events of high priority were covered first as news items and in headlines. The high priority was officially justified and additionally explained in introduction texts (leads). Events of lower priority were in the second part of newscast, their official justification was not that explicit, and their coverage was not frequent. 
BIG

\section{CENTRAL NOMENCLATURAL EVENTS}

- covered in special reports modifying the program, special bulletins instead news reviews

- references to most other texts

- examples: Central congress of the Communist party

\section{EVENTS OF SOVIET FOREIGN POLICY}

- covered in special reports, thematic broadcasts, special commentaries related to selection of feature films, theatre performances

- examples: covering Finland, India, Jugoslavia

\section{EVENTS OF RITUAL YEAR-ROUND}

- extensive coverage at least once in a year

- references to other texts

- examples: miners 'day, international women's' day

\section{ANNIVERSARIES, BIRTHDAYS}

- neo necessarily every year

- do not contain so many references to other texts

- examples: personalities related to the history of Soviet Union, sometimes personalities from West (George Bernard Shaw, Jean Sibelius)

\section{RANDOM EVENTS}

- achievements of agricultural and industrial enterprises, visits of foreign delegations, observations of daily life of Soviet people

FIGURE 2. Hierarchy of events in early news texts in the mid-1950s.

Events with high priority were related to the Communist Party institutions and central authorities. Party congresses were covered as special reports (special newscasts). 
According to official agenda setting, every year was divided into important periods and moments according to year-round rituals. Most of those events had fixed dates, such as the Day of Wisdom, Miners' Day, and Women's Day. Another periodisation was related to 5-year plans, and periods based on agriculture were covered extensively, such as spring sowing, haymaking, and harvest.

Those were routine, ritual events that re-occurred every year, and in journalistic coverage, the same symbols and metaphors were used. For powerholders, rituals were used to maintain the political status quo. Every ritual worked as a stabilisation tool, demonstrating that nothing ever changed. Soviet scholars stressed the importance of rituals. Ritual was "seen primarily as a form of political socialization, as a way of inculcating the norms and values of the dominant ideology" (Lane 1981: 19).

Soviet powerholders tried to manage mechanisms of synchronisation by carefully selected official and ritual events. According to official principles, events could not be random as provided by everyday reality, but were rather signs of important developments and events that formed the history of the present (Прохоров 1973). But there was another set of mechanism synchronization, a sort of natural synchronization shaped by the media itself as journalistic texts should be taken as journalistic even in a totalitarian society. Television broadcasts often became sort of independent (not necessarily directly managed by power) events; also, stories about culture and ordinary people became events. From the official point of view, they were harmless, but as a mediation of experience, they became important for reality construction.

An analysis of deixis enables one to see the dominant position regarding the building of a time/space of reality. The main reference point was created by the we position. Thus, the person to whom the message was directed also became part of reality construction. Such a position is inclusive (an exclusive we position is also possible). Often the point of reference was created by putting abstract collective actors (such as Soviet people, progressive humankind, all peace-loving nations in the world, etc.) into the role of main active subject. Also, the private person (a worker, a farmer, or a student) was used to represent the entire collective (for the entire collective of a factory, for instance). Collective became more important than a single person.

\section{SCRIPTS AND PICTURES - RELATIONS BETWEEN THE VERBAL AND VISUAL}

The moving image is an important tool for mediating perception and experience. At the beginning of television broadcasting, only centrally produced newsreels were available. But the medium was no longer the cinema. Vladimir Sappak described the transformation of cinematic truth: "During its first years cinematography was taken as an art of absolute truth. But when now someone says 'Exactly like in a movie!' it is not any more used as a synonym for something precise and documental but for illusory and unreal" (1965: 145). For television, the picture is often a direct reference to something-a specific mediated perception of reality. The demonstration of real events can even be live; i.e., continuous visual referencing to reality or synchronisation with an event as it unfolds becomes possible. Such a relationship is not possible in any movie. Thus, television as a new medium had to manage new kinds of relations of reality and its visual representation.

During the 1950 s, the only way to record images was to film them, but it became more and more awkward for television production. Another option was to show photos during live broadcasts. A special stand was installed in the studio. Due to a lack of funding, Tallinn Television Studio could not design proper static cardboard captions (written titles and slogans) ${ }^{2}$, and the management could not hire a designer initially. But those gained importance, especially in newscasts. Later, important

The first animated caption (programme signature) was broadcast on 6 February 1956 (Peep 2009). 
ideological slogans were presented as captions between news stories. Broadcasts like "A commentary in front of the world map" became popular, and the map on the wall became part of the visual message.

In technical terms, only two channels could be used for live pictures from the studio, and there were only two switchboardconnected cameras to record speeches and concert performances in most cases. Another option was to plan some live action in the studio. The demonstration of products and fashion shows to demonstrate the success of the Soviet industry to bring happy reality to live studio but not for advertising. Official policy had "spurned advertising as economic waste and has at times denounced advertising and other "bourgeois capitalistic' devices as competition, production differentiation, and installment buying" (Markham 1964:31). Sometimes, athletes were invited to show different sports (boxing and fencing, for instance).

The activity demonstrated in the studio was not very realistic; it was more or less simulated, staged, and carefully rehearsed beforehand. When film cameras were finally used (several months after launching the television station in Tallinn), journalists became much more independent in creating different combinations of visual references to reality. Probably the first illustrated story was aired on 18 September 1955. Pictures were not taken from a newsreel, but were especially filmed for television coverage. The live monologue delivered by the rector of Tartu University was illustrated by some sequences of shots. Those shots did not convey any actions; they were just static shots of buildings and streets without people. In November 1955, the television studio received two cameras for live outside broadcast, and it became possible to broadcast programmes from concert halls.

Questions about the relationship between the visual and the verbal gradually became more complex. It was possible to analyse whether a picture conveyed a message of experience or pointed out something in reality (i.e., built a certain ostensive link between reality and its representation). From
1955 to 1960, pictures became an important component for television stories. It was discovered that a good picture did not need long voice-overs. With the development of television journalism, the management of the relationship between the visual and the verbal became better. Journalists learned to avoid telling exactly what was presented visually and to give some additional verbal information when it was needed. Interestingly, more complex metaphorical relationships were avoided, which is why direct relationships were preferred. Vague metaphors could evoke harmful interpretations of the political system, that is, the state.

The first Soviet television journalism textbook (issued in 1960) described innovative methods applied at the Tallinn television studio. Journalists could also become directors for producing news stories; that is, they could be responsible for the pictures.

In terms of visual communication, the television audience expected a bit more than was provided by the television broadcasting. Viewers' reactions were summarised in a special Q\&A type of programme (called "Break"3). One of the questions (19 October 1956) was why television broadcasts were mainly illustrated with still images, photos, and figures. The director general of the television studio explained that there was lack of cameramen (10 to 15 were needed, but just 2 were employed during first months of operation). He added that the film laboratory was also poorly equipped.

Censors often could not recognize images prohibited by the law. For instance, detailed shots of airports or big fuel tanks were not allowed. GLAVLIT's annual report from 1958 mentioned that in some cases, violation of the law was discovered after a television programme had been already aired.

\section{MANAGING CONFLICTS - REALITY INTERPRETATION MECHANISMS IN EARLY TELEVISION JOURNALISM}

As described above, the experiential mechanisms described earlier help to 
define presentness and everyday time and space. The latter was in constant change. Soviet powerholders tried to modify the mechanisms of journalistic perception and its representation by specific agenda setting. In every public sphere (and even in a totalitarian society), there are collectively shared ideas. These can be abstract and/ or related to collective memory. Collective meaning-production can be handled as a long-term process (compared to short-term representation of perception). For instance, Estonians collectively shared some specific ideas about their fate in history, as well as ideas about the East and West, wealth and poverty, and progress and crisis.

Markers of rhetoric and figures of speech, such as metaphors, enable one to identify essential discursive strategies in early television texts. Those strategies were used to promote certain values and to explain what was good or bad, what was acceptable or unacceptable, and what could not be tolerated. Such interpretation mechanisms are based on collectively shared meanings. Paradoxically, all the rhetoric used in these journalistic texts demonstrated the problems with public opinion in Soviet Estonia. For instance, it was necessary to stress a remarkably happy fate of Estonians when most of the audience obviously did not share that position. Many people had memories from the period of Estonian independence (1918-1940).

The overwhelming strategy in the scripts was to shape (construct) knowledge about the happiness of Soviet people and the everlasting progress of socialism. Happiness was not just an emotion, but was also a self-evident belief and a collectively shared reality. The following is an example of rhetorical management:

There is no place in our entire homeland, without flapping flags and glistening banners, where joy of sprouting life does not join to joyful anthem of workers dedicated to our socialist Soviet homeland, on honour of our government and glorious communist party. It is the party, whose govern- ing enables with golden hands of our workers, peasants and intellectuals to raise higher and higher the wall of the building of communism. Crowds of workers are responding to decisions of the $20^{\text {th }}$ Congress of Communist Party with new creative victories in factories, on kolkhoz fields and in building sites and laboratories. (Special programme dedicated to the 1st of May, Workers' Day, broadcasted on 1 May 1956)

This was a special newscast (instead of a regular news review) that was part of the year-round rituals. Specific rhetoric devices, such as negation and even double negation, enabled the Soviet powerholders to construct beliefs of happiness. Also, strong, additional adjectives, like glorious party and golden hands (meaning the ability to create whatever was needed), and phrases, like raising higher and higher, created the illusion of constant positive development. Victory is an abstract term that was often used in various texts. But it is not often clear what it meant - victory over what? In addition, there was no option to not celebrate Worker's Day.

First, the television scripts reveal principles of a certain conflict management. There could not be conflicts with power or inside power and also between peace-loving nations or inside progressive mankind. But conflicts could occur in some foreign countries (capitalist countries in most cases) or inside a private person, the Soviet citizen. Conflict was seen as an important ingredient for any journalistic story that created a dialect of different characters, positions, and opinions. But according to Marxist principles, victory was always reserved for progressive forces of society. In western media, most news texts were negative and critical towards powerholders. But in the Soviet Union, such kind of criticism was not tolerated. Reality had to exist without any essential problems. According to standards of Soviet journalism, news text could not be sensational and could not produce any purposeless attention or unnecessary anxiety. 
It is absolutely clear that bourgeois journalism, which more and more becomes part of active capitalism monopoly has become a weapon in hands of owners of media outlets. It is journalism hunting progressive forces, who are standing for people's rights. It is slandering the Soviet Union and socialist countries, stirs up cold war and it all means profit for owners. There is an interesting disagreement. Soviets claimed that their news texts could not be sensational, but they were not neutral at all, unlike the western principle of news neutrality and impartiality. (Satjukov 1960: 63)

Foreign news was a typical playground for representing conflicts. There were good and bad countries, allies and enemies. For instance, according to a news text on the Suez crisis:

The canal build by labour and blood of Egyptians was seized by imperialists. The decision made by the Egypt government gives people back their belonging. Government of Egypt guarantees, that it ensures full freedom of traffic in Suez Canal. But imperialists raised uproar due to decision. They are mourning all the millions, which they lose when the canal was nationalised. They are horrified by the chance that Egypt's decision could become a model for other countries where imperialists still are domineering. (Broadcast " $A$ commentary in front of the world map", 13 October 1956)

This script represents an obvious presupposition: Egypt had suffered unfairly. Emotional and rhetorical television commentary was a news genre of its own kind that was prepared by special people authorized commentators. Any material from foreign sources was considered classified, and the commentators had access to sensitive materials and worked under tight control.
Different rhetoric devices often represented conflict between the history and the present. Ideas about burdensome history emphasised that the present was the best time for Soviet people. History was described as a story about fighting for good and eliminating inequality. Soviet concept was to prove that Estonian independence was another example of bad history. Only the period of Soviet rule opened peoples' eyes. Bourgeois Estonia was a society without vision.
Only by police rule and with help of their baton the bourgeois power could last. It was a power, which brought welfare only for handful of capitalists. For working masses it only bought woe, misery and suffering. And such a bourgeoisie that could remain in power by bayonets was constantly worry- ing about its fate. They increased the number of troops, arranged military manoeuvres and was wrapped them- selves up in military adventures. They built concrete fortifications on eastern border. All the workers 'gazes were on the border. People on the other side knew what could be life without mas- ters and oppressors. (Programme on the anniversary of the socialist revolt in Estonia, 21 June 1956)

Here the idea of a minority-driven and ill history is dominantly conveyed. It was not directly said, but it could be concluded that a better solution was on the other side of the border - in the Soviet Union.

Personality was another field of conflict conveyed in various scripts. The individual could be responsible for insufficient understanding of all the achievements of the society as a whole and all the policies implemented by the powerholders. It was a conflict between the seeming and real, the imaginary and the trustful. Seeming was a category that involved doubts and uncertainty. The scripts hinted that empty illusions were typically produced in capitalist societies, where everything nice was just an empty declaration and did not reflect 
anything real. Capitalist democracy was depicted as something based on empty promises. All the policies in capitalist societies brought disappointment for masses:

Soviet constitution guarantees for every person right to job and have a rest. The same is mentioned in constitutions of capitalist states. But under capitalist circumstances those rights cannot be provided. There an atrocious economic competition and anarchy of production rules. Tens and hundred workers are forced to wander around to seek for a job. But those who have a job are dependent on exploiters' mood. In the soviet constitution the ensuring of declared rights are on focus. (Newscast dedicated to trade union organisations, 9 August 1956)

The main argument in the programme was based on faulty capitalist legislation. The script stresses that it did not matter what the country was. For the propositions describing the enemy's world, a passive voice was used. In the propositions concerning the Soviet Union, an active voice was more used with an active collective actor (such as the Soviet government and the Soviet people).

One relatively safe territory for criticism was related to household matters. It was also a sign of active interaction with the audience as the television studio encouraged people to send in letters and to contribute comments. Small practical problems of daily life were covered in various stories. One of the genres used for those stories was satire even in newscasts. Satire was officially tolerated by the ruling communist party. The leader of the party, Sergei Khrushchev, once explained that satirists are journalists and that satire is journalism:

When satire is jeering at one or another vice, remnant or shortage, it prevents people from diseases and helps to root out any shortcoming. Thus satire should remain in the arsenal of our party and people, it should shoot everything, which intervene in our move towards communism. (Khrushchev's speech to the members of the Union of Writers in 1956).

The following is an example of a satiric news story:

Nice, handsome books. What else, let's start reading. Oh, but it is such a start, does not give any inspiration for reading! Lets open this "open" book. It is already open, but not where it is supposed to be. And look at this. Two empty pages, no text. And look at the wrinkled and ugly pages in a brand new book! The title is "Local airdefence". Interesting indeed. Do they say anything, how to protect yourself against such books? (News review "Aktuaalne Kaamera", broadcasted 21 October 1956).

Here an active rhetoric, virtual dialogue with the audience is presented, which was unprecedented for a news text. Irony means that affirmation stands for negation. Picture close-ups of the book were used as well as some general shots. It formed another irony based on the controversy of pictures of the production defects and the pathetic verbal message. For political stories, such an approach should have been unthinkable.

\section{FROM PASSIVE MEDIATOR TO ACTIVE CONTENT PRODUCER}

From the journalistic point of view, television started initially as a middleman of various audio-visual performances. Some of them were produced as live production, such as lectures on various topics, short concerts, or theatrical pieces. The role of television presenters was rather marginal: They mainly introduced people in the studio. The interview was considered to be a risky venture, in both technical and ideological terms. Most of the performances were scripted. Another part of the programme consisted of precooked newsreels, meaning that both editorial and technological control was given away. For this kind of precooked 
content, introduction texts were minimalistic, but television presenters slowly started to add some significant details to their introduction texts. Some hints were given regarding what to pay attention to and what to take into consideration. Step-by-step texts gained a certain informative status, a new kind of relationship with the audience, and a new kind of television rhetoric. This served as a fruitful basis for the evolution of an informative television broadcast, which was a new type of in-house production.

The management of the television studio in Tallinn submitted a proposal to Moscow to start the production of its own newscast (Piip's letter to the Central Board of Information on 19 April 1956). But Moscow said it was too expensive and admonished to the management to respect the limits set by the budget approved by Moscow. Less shooting was the solution proposed by the central authorities. The Central Board of Information promised to provide more newsreels from different Soviet republics, as well as feature films produced in other regions of the Soviet Union. To shoot something especially for television was seen as a big exception (Roth-Ey 2011: 230). However, managers in Tallinn decided to start the production of their own news reviews. They did not wait for the final official response from Moscow. The first television newscast was aired on 11 March 1956 and was a television round-up, that is, a news review. The name for the show was taken from East Germany (DDR) - German Aktuelle Kamera was translated into Estonian as "Aktuaalne Kaamera". Obviously, in the DDR, there was not any special concept behind the name; it was simply shorter than Fersnehnachrichten (the television news in German) (Bösenberg 2008: 26).

Was it a true news programme according to modern criteria? Did it provide any information? It is hard to say if one takes the context into consideration. Central authorities did not have a clear understanding of creative and journalistic tools of television broadcasting. From their perspective, the news review was more like theatre and not for delivering information. In most cases, the stories were approved two weeks before production. Thus, there was no particular danger for the political system. Planning of the news reviews became a natural part of planned economy, but subject of the planning was not very clear.

In financial terms, the Department of Newscasts became the biggest of the television studio. The second was the Department of Industrial Programmes and the Department of Agricultural Programmes. The names of departments reflected the priorities of the official agenda setting.

Table 2 is a modified dopesheet (running sheet) of one newscast "Aktuaalne Kaamera" aired on 19 October 1956. The picture material did not survive the fire in the 1960s. However, analysis can be done according to handwritten remarks added to the typed scripts. The tenth panorama numbered was diverse from the point of view of genre. The panorama was cut into seven independent items. It contained official news text, a journalistic description (reportage), short interviews and even puns. The newscast was structured with cardboard titles. Such a method was borrowed from classic cinema newsreels. In such headings, there were no active verbs - they were just used for naming as well as adding some ideological stand (such as hinting that the anniversary of the October revolution had to be celebrated by victories). The newsreader was not visible for most news items, only appearing at the beginning of the photo contest story. Obviously, he or she was not the host of the show and there was no need to have greetings at the beginning; instead of closing remarks at the end, there was a satirical text containing some elements of entertainment.

A certain evolution from an official standpoint to a simpler and more human point of view can be seen in the early Estonian television news reviews. The most official texts were in the beginning and the most entertaining were at the end. The author's position would even change throughout a newscast. In the particular 


\begin{tabular}{|c|c|c|c|c|}
\hline TITLE/Topics & GENRE/Picture & ACTORS & MESSAGE & NOTES \\
\hline $\begin{array}{l}\text { 1. OPENING } \\
\text { SIGNATURE } \\
\text { Topics (according } \\
\text { to dope sheet): } \\
\text { Guests from Japan } \\
\text { honoured }\end{array}$ & $\begin{array}{l}\text { NEWSTEXT/ } \\
\text { Film shots as } \\
\text { illustration }\end{array}$ & NEWSREADER & $\begin{array}{l}\text { The Japanese } \\
\text { delegation honoured } \\
\text { Soviet soldiers of } \\
\text { WWII }\end{array}$ & $\begin{array}{l}\text { The item was added } \\
\text { at the last moment, } \\
\text { as sort of breaking } \\
\text { news }\end{array}$ \\
\hline $\begin{array}{l}\text { 2. General title: } \\
\text { BEFORE GREAT } \\
\text { OCTOBER DAY } \\
\text { Topics: } \\
\text { Workers' } \\
\text { achievements }\end{array}$ & $\begin{array}{l}\text { REPORTAGE/ } \\
\text { Film shots as } \\
\text { illustration + } \\
\text { statement ('talking' } \\
\text { head) }\end{array}$ & $\begin{array}{l}\text { NEWSREADER } \\
\text { Factory directo }\end{array}$ & $\begin{array}{l}\text { Ski factory has } \\
\text { mew facilities. } \\
\text { It is the best way } \\
\text { to celebrate the } \\
\text { anniversary of the } \\
\text { October revolution }\end{array}$ & $\begin{array}{l}\text { The item was } \\
\text { planned weeks } \\
\text { before airing }\end{array}$ \\
\hline $\begin{array}{l}\text { Topics: } \\
\text { Honoured } \\
\text { dressmaker }\end{array}$ & $\begin{array}{l}\text { REPORTAGE/ } \\
\text { Photos as } \\
\text { illustration }\end{array}$ & NEWSREADER & $\begin{array}{l}\text { One dressmaker of } \\
\text { Klementi factory is } \\
\text { able to produce } 1.5 \\
\text { times more than } \\
\text { others, more than } \\
\text { planned. Her portrait } \\
\text { will be displayed on } \\
\text { board of honour }\end{array}$ & \\
\hline $\begin{array}{l}\text { 3. Title: } \\
\text { WELL-EARNED } \\
\text { RECOGNITION } \\
\text { Topics: Pension } \\
\text { increases }\end{array}$ & $\begin{array}{l}\text { REPORTAGE/ } \\
\text { Photos as } \\
\text { illustration }\end{array}$ & $\begin{array}{l}\text { NEWREADER/ } \\
\text { JOURNALIST } \\
\text { Retired people } \\
\text { interviewed }\end{array}$ & $\begin{array}{l}\text { Veterans of paper } \\
\text { pulp factory are } \\
\text { gathering in the } \\
\text { club of the factory. } \\
\text { As new law provides } \\
\text { better allowances, } \\
\text { many decided to } \\
\text { retire. Interviewees } \\
\text { expressed their } \\
\text { gratitude to the } \\
\text { government. }\end{array}$ & $\begin{array}{l}\text { News story planned } \\
\text { many weeks before }\end{array}$ \\
\hline
\end{tabular}

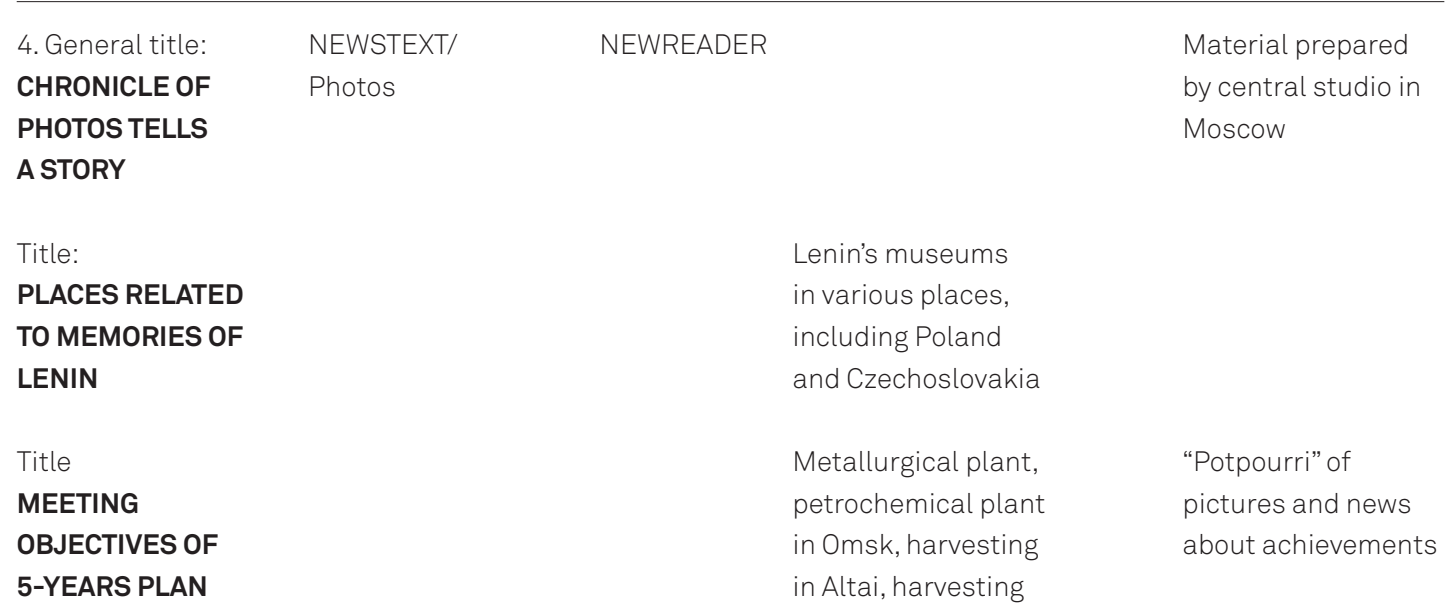


cotton in Tajikistan,

new TV tower

in Chelyabinsk,

exhibition centre

in Frunze, holiday

resort near

Magadan, small cars

Title:

DRIFTING ICE

STATION

EXTRA-ORDINARY

JUBILEES
Hard work continues

to investigate the

North Pole

One miner had

102st birthday, also

another man in

Azerbaijan

\section{Winners of photo}

Expert is used as

5. Title:

NEWSTEXT/

NEWSREADER/

contest were

performer

announced. TV

studio artist-

photographer

delivered his

comments.

$\begin{array}{ll}\text { 6. Title: } & \text { NEWSTEXT/ } \\ \text { TALLINN RAILWAY } & \text { Photos + journalistic } \\ \text { STATION } & \text { commentary }\end{array}$

NEWSREADER

\section{Booking by}

telephone became possible. Waiting rooms are bigger.

But luggage storage

rooms are obviously too small, and some of the platforms are still not ready.

\section{Title:}

CAUTION, IT TEARS

\section{SATIRICAL}

COMMENTARY
NEWSREADER

Shops sell items that do not meet quality standards.
Contains critical

journalistic remarks read by the newsreader

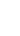


news broadcast there was also a live interview with three people, and an expert's commentary as a separate news piece.

The story about Japanese guests is an example of breaking news of its kind. That particular story was handwritten and added at the last moment. According to the foreign policy of the Soviet Union, Japan was not as important as India, China, or Finland. But any remarks about Japanese-Soviet relationships were avoided, as well as general information on the visit of representatives of the Japanese workers' union. One of the guests made the following statement:

Comrade Itikava said in his speech: "We are here as first quests from Japan, who

come to Soviet Estonia and we are infinitely happy for the chance to fulfil our duty of honour. To remember those who gave their life to liberate the capital of Soviet Estonia from fascists occupants." (Newscast "Aktuaalne Kaamera", aired on 19 October 1956)

According to the modern understanding of the value of a news item, the first news item (Table 2) did not contain many newsworthy ideas, because there was not much information about the visit of the Japanese delegation but was mostly about their admiration of the Soviet Union.

Interestingly, the third item in the review was an interview with three retirees. Questions were asked by the journalist and not by the newsreader. There was no exact script for the answers. It seems that participants were trained to give an interview, and then a plan was written for the newscast. In some other newscasts, interviews were scripted in detail beforehand.

The last three texts demonstrate that acertain dialogicality is in small arguments. The rhetorical question in the news text (What is a good photo?) activated perception and encouraged the audience to think about what they considered a good photo. Text about the railway station revealed some public criticism not about system, but rather focused on some small aspects of seen as a new means of disseminating official doctrine. Control was thus taken to an extreme - the authorities provided the final script for public communication, required that script strictly adhered to their restriction, and called the resulting practice "journalism". Yet, gradually over time, the television scripts succeeded in shedding their official garb. Step by step, television started to address the public in its own name and to reflect the reality surrounding it. The text of emerging television programmes soon started to engage the viewers, and the new medium quickly built up its own audience. The initial relationship of television and reality developed into a web of relationships that took into account the specific nature of the channel and relied on text as well as pictures. The communication of information started as announcements made between shows. The first newsreel produced specifically for television was aired on 11 March 1956. A certain modal division soon emerged between the first and the second half of the programmes. The first part of Soviet newscasts was official and nondialogic. The second part, on the other hand, was of dialogic nature, with questions being addressed to the audience with discussion and satire. This is also how average viewers perceived those shows. They understood that programmes had to have a section that reflected the Soviet government's version of reality, and that in addition to that section, programmes had other parts that related to their down-to-earth reality that they experienced first-hand and which portrayed the ups and downs of their life.

That audience of the new medium soon became a public in its own right - an independent television public. Even in a totalitarian setting, the powerholders were unable to establish complete control over that public; thus, they could not control all possible relationships that could possibly arise from interpreting and recognising the various texts. The story of television's first years in Estonia is partly a story of a new medium of the times, of a completely new environment for the construction of journalistic facts. 
daily life of the Soviet people. The very last text is entirely satirical, with lots of openended questions and emotional arguments. But the text is not about Soviet production or a Soviet system - it is just a concrete product as a funny exception.

\section{CONCLUSION}

Analysis of the texts of Estonian television from the period of 1955-1958 shows how a new communication environment was created in a totalitarian society. To some extent, it was included in a formalised ideological sphere, but also in a more informal sphere, where members of society could exchange knowledge and perceive themselves. It shows that public communication cannot be controlled entirely by the state. From an institutional point of view, there was no clear official understanding of how to use the new communicative space most effectively as an effective institution to educate and guide the masses.

The initial period of the ETV demonstrates a complex, multilayered situation. Broadcasts intended for Finland were undertaken on orders from the Soviet authorities to intensify the ideological campaign conducted against Finland. ETV staff, however, was able to use the newly established media channel to develop a media organisation focused on the interests of Estonians as a distinct ethnic group. The new technology created an opportunity to project a nationwide representation of reality that was unattainable in print media under Soviet censorship. Pictures (visual text) allowed for a considerably expanded range of information to be transmitted and were impossible for the authorities to control to the last detail. Censors lacked the experience and the technology to analyse the pictures. The Soviet government, while it did employ technology to serve its political ends, was unable to exert complete control over it.

The 1950s saw the formation of the main genres and canons of television journalism of that period. The first television scripts were very similar to scripts of official communications of the pre-television era, suggesting that television was simply
In Soviet society, the principle of planning informed not just the economy, but also the representation of reality. News texts about reality were planned a considerable amount of time before a broadcast. These plans, in their turn, were based on resolutions made at party conventions and on directives from executive party bodies.

Thus, one can speak of what may be termed "planned reality".

When Nikita Khruschchev came to power in the Soviet Union, the media was given some slack for critically engaging the reality it operated in. This allowed newscasts in Soviet Estonia to include material that strengthened the national identity of ethnic Estonians. In this way, official texts were used to resuscitate discourses that from the point of view of the Moscow authorities, would previously have skirted dangerously close to being treasonous. Although news organisations were still subject to control by the authorities, this was no longer the iron-fisted affair that it had been during the Stalinist period. As for political news, this had to be the established line as before, yet criticism and debate were encouraged in areas related to people's emotions and individual responsibilities such as culture and everyday life. In these areas, journalism began to flourish, and novel news genres appeared - those of the commentary and of the live report.

The example of emerging television as a new technology during 1950 in Estonia raises questions about universal features of any media technology. For powerholders, what are opportunities to control content and meaning production institutionally? It seems that these are rather limited. The journalistic reality construction is partly determined by the sociopragmatic mechanism related to the public sphere. It cannot be fully predetermined and therefore can be said to operate as an open system even in a totalitarian society. The openness of the system is guaranteed by its components the authorities, the public, and the media. What varies across different types of society is merely the institutional mechanism of exerting control over the media, which 
has little or no impact on substantive issues concerning the reflection and interpretation of reality.

\section{REFERENCES}

Aleksejev, S.; Kubarkin L.; Losseva, A. 1955. Kuidas toimuvad televisioonisaated. Tallinn: Eesti Riiklik Kirjastus.

Brooker, P. 2009. Non-Democratic Regimes.

Basingstoke: Palgrave Macmillan.

Bösenberg, J.-A. 2008. Die Aktuelle Kamera.

Nachrichten aus einem versunkenen Land. Berlin: Verlag für Berlin-Brandenburg.

Bühler, K. 1990. Theory of Language. The Representational Function of Language. Trans. D. F. Goodwin. Amsterdam, Philadelphia: John Benjamins Publishing. van Dijk, T. 1988. News as Discourse. Hillsdale: Lawrence Elrbaum Associates.

Fauconnier, G. 1999. Mappings in Thought and Language. Cambridge: Cambridge University Press. Friedrich, C. J.; Brzezinski, Z. K. 1956. Totalitarian Dictatorship and Autocracy. Cambridge: Harvard University Press.

George, G. 1964. 'On content analysis and critical research in mass communication'. - L. A. Dexter, D. M.

White (eds.), People, Society and Mass Communications. Glencoe, IL: The Free Press, 85-108.

Gerbner, G. 1973. 'Cultural indicators: The third voice.' G. Gerbner, L. P. Gross (eds.), Communication Technology and Social Policy. New York: John Wiley \& Sons.

Gunter, B. 2000. Media Research Methods: Measuring Audiences, Reactions and Impact. London, Thousand Oaks, New Delhi: Sage.

Halliday, M. 2004. An Introduction to Functional Grammar. London: Hodder Arnold.

Lane, C. 1981. The Rites of Rulers: Ritual in Industrial Society - The Soviet Case. Cambridge: Cambridge University Press.

Lauristin, M.; Vihalemm, P. 2008. 'Kultuuriajakirjad sotsioloogi pilgiga' - Keel ja Kirjandus, 1-2, 3-15. Lauristin, M.; Vihalemm, P.; Tallo, I. 1997. 'Poliitilise kultuuri areng Eestis'. - Sirp, 17 and 24 October. Lõhmus, M. 2002. Transformation of Public Text in Totalitarian System: A Socio-Somiotic Study of Soviet Censorhip Practices in Estonian Radio in the 1980s. Turku:Turun Yliopisto.

Markham, J. W. 1964. 'Is advertising important in the Soviet economy?' - Journal of Marketing, 28, 2, 31-37. Peep, H. 2009. Eesti Televisioon 1955-1990.

http://www.hot.ee/etvajalugu/index.htm (28 September 2013)

Roth-Ey, K. J. 2011. Moscow Prime Time: How the Soviet Union Built the Media Empire that Lost the Cultural Cold War. Ithaca, Lonon: Cornell University Press.

Sappak, V. 1965. Televisioon ja meie: neli vestlust. Tallinn: Eesti Raamat.

Satjukov, P. A. 1960. 'Nõukogude ajakirjanikud on kommunistliku partei järeleproovitud abilised'. - Nõukogude ajakirjanike esimene üleliiiduline kongress 12.-14. november 1959. Kongressi ettekanded ja otsused. Tallinn: Eesti NSV Ajakirjanike Liit.

Treufeldt, I. 2012. Ajakirjanduslik faktiloome erinevates ühiskondlikes tingimustes. Doctoral Dissertation. Tartu University, Faculty of Social Sciences and Education, Institute of Journalism, Communication and Information Studies, Tartu.

Tuchman, G. 1980. Making News: A Study in the Construction of Reality. New York: The Free Press. Veskimägi, K.-0. 2005. Kuidas valitseti Eesti NSV-d. Eestimaa Kommunistliku Partei Keskkomitee büroo 162 ülesastumist 1944-1956. Tallinn: K.-O. Veskimägi. Wodak, R.; de Cilia, R.; Reisigl, M.; Liebhart, K. 1999. The Discursive Construction of National Identity. Edinburgh: Edinburgh University Press.

Фирсов, Б. М. 1971. Телевидение глазами социолога. Москва: Искусство.

Прохоров, Е. П. 1973. Публицист и действительность. Москва: Изд-во Московского университета. 